\title{
Transition, reflection, rethinking and reimagining: The relevance of Black liberation theology in South Africa post-1994 - a tribute to Vuyani Vellem
}

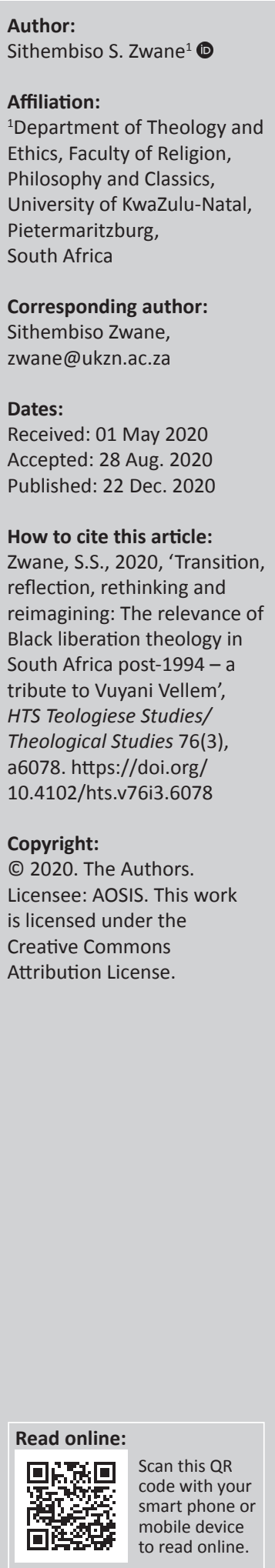

This article pays tribute to Vuyani Vellem's work on the relevance of Black theology of liberation (BLT) post-1994 in South Africa. Firstly, this article provides a synopsis of the political and economic 'transition' of South Africa before and after democracy. Secondly, the article seeks to provide a candid 'reflection' on the BLT trajectory, especially its critique of white racial theology. Thirdly, the article attempts 'rethinking' the location of the Bible and the black interlocutor in the post-liberation context. Fourthly, the article attempts to 'reimagining' the relevance of BLT post-1994 with a focus on proposed contemporary theologies.

Contribution: The manuscript is responding to a special issue honouring the legacy and scholarship of the late Prof Vuyani Vellem who contributed immensely to Black Theology of Liberation (BTL) in the South African context. The manuscript attempt to dialogue with Vellem on key issue that he raised, especially racial issues and the role of the recognition of the black interlocutor. The VukaniBathoTsohangBatho special issue is dedicated to this great son of the soil who distinguished himself through research in the area of BTL challenging issues affecting the majority of black people, issues like racism, land, unemployment and economic inequalities in South Africa. This manuscript engages with some of these issues hence its relevance to the journal. The manuscript argues that as long as social and economic injustices exist, Black Liberation Theology (BLT) will remain relevant post 1994 dispensation.

Keywords: Black Liberation Theology; racism; Churches; the Bible; Black interlocutor and the poor.

\section{Introduction}

This article recognises the existing scholarship on the question of the relevance of BLT post 1994 in South Africa (Maimela 1994; Tshaka \& Mabathoana 2010; Adebo \& Godfrey 2013; Hankela 2014; Kgatle 2018). As Vuyani Vellem would argue, BLT is relevant today as it was during the apartheid era. Vellem would underscore that more still needs to be done to protect political gains and to ensure economic emancipation. South Africans, especially the black poor working class, are desperate for economic emancipation post-1994. The triple challenge of chronic unemployment, abject poverty and huge income inequalities persists unabated. Elina Hankela (in his article entitled 'we are not yet liberated in South Africa') employs the concept of humanity as core in the struggle (s) for liberation (Hankela 2014). The elusive economic liberation remains a fundamental challenge. The pertinent question therefore is, what is the role of BLT post 1994 in South Africa?

The importance of political and economic transition from oppression under the Dutch and British colonies paved the way for democratic dispensation characterised by anxiety and excitement. South Africa became a battle ground from the 17th to 18th century under the colonial rule of the Dutch and British imperialists, respectively. The black majority suffered severely as a result of this act of oppression and marginalisation. This was followed by a transition from colonial rule to political democracy in 1994. The democratic process was achieved through collaboration between the political and ecumenical movements in South Africa.

The contribution of BLT created a conducive environment for a candid reflection and challenged white racist theology that perpetuated white supremacy in South Africa. A paradigm shift from a white oppressive theology to a BLT was inevitable. Attempts to unite both white and black

Note: Special Collection entitled VukaniBantuTsohangBatho - Spirituality of Black Liberation, sub-edited by Fundiswa Kobo (UNISA) and Rothney Tshaka (UNISA). 
churches have been made in Southern Africa, especially by the Reformed and Protestant traditions. Reformed and protestant traditions were reflected in the Roman Catholic Church, the Uniting Presbyterian Church of Southern Africa, the Uniting Reformed Church of Southern Africa, the Evangelical Lutheran Church in Southern Africa, the Anglican Church in Southern Africa and the Methodist Church in Southern Africa. The primary focus was the integration of racially diverse congregations into one body of Christ in the Southern African region. However, white racist theology premised on the notion of supremacy further polarised the church in Southern Africa. During the apartheid period, the Bible was used to instigate division rather than unity amongst the churches.

The location of the Bible amongst the 'black masses' requires rethinking about the critical role of BLT. The Bible offers both redemptive and oppressive narratives to black people depending on their hermeneutical approach and contextual realities. The Bible remains what Itumeleng Mosala calls the 'Site of struggle' (Mosala 1989:32) for the majority of black working class communities who have experienced the Bible both as oppressive and liberating text, which underscores its ambiguities and contestation. There is neither universal nor generic appropriation of the Bible. It is polemic and a contested text for both the community and the academia. In the context of racial exclusion, the Bible became an instrument to undermine black interlocutors in the process of interpretation. The position of a black interlocutor justifies a discussion of the relevance of BLT after the 1994 period. Despite attempts being made to ensure the inclusion of black working class in the main stream economic and political activities, a meaningful participation remains elusive for the majority of black people.

The realty of many black interlocutors necessitates a discussion on the relevance of BLT in post-1994 democratic dispensation. Black liberation theology finds expression in the reimagining of contemporary theologies that seek to challenge the economic and political status quo in both public and private institutions in South Africa.

\section{Political and economic periods: Transition}

The dawn of democracy in 1994 witnessed the ushering of the new dispensation marked by vociferous cheering from the majority of black working class communities, which signalled hope in the midst of despair under the apartheid political and economic hegemony that lasted for decades.

Economist Sampie Terreblanche (2002) provided the history and analysis of the systemic relationship between political and economic power, especially land and labour. This historical record is an indication of the socio-economic and political inequalities based on racial segregation.
The first phase is the transition between colonial regimes involving political and economic institutions in South Africa. In terms of the scope of this article, it is from the 17 th to the 18 th century. Terreblanche (2002) identifies a number of critical systemic periods in the South African political and economic history, especially 'the mercantilistic and feudal system institutionalised by Dutch colonialism during the second half of the 17th and most of the 18th century (1652-1795)' (p. 14). The Dutch were the first to arrive in South Africa, with Jan van Riebeeck and the Dutch East India Company settling in the Cape. This was the beginning of the political and economic exploitation of black people characterised by racial segregation. This colonial period probably lasted for 143 years before a transition to the British rule.

The British colonial and racial capitalism (1795-1890) and a related system of British colonial and mineral capitalism (1890-1948) (Terreblanche 2002:15) introduced the intensification of unfree labour patterns evident when the Afrikaner-oriented National Party won the general election of 1948; even though they 'did not drastically transform the economic system of racial capitalism institutionalised by the English establishment, it used its political and ideological power to institutionalise a new version of it' (Terreblanche 2002:15).

The second phase is the transition from colonialism in the 17 th to 18 th century and to 19th century democratic period marked by economic policy shifts, beginning with the introduction of the Reconstruction Development Programme (RDP) as macroeconomic policy framework by President Nelson Mandela's administration in 1994. This was a step in the right direction in responding to the needs of an inclusive economy.

Vellem (2020) states that the transition from apartheid to democracy was a 'fraudulent discourse' (p. 7). The 'fraudulent discourse' refers to the negotiated settlement that led to the democratisation process. Furthermore, he argues that 'democracy cannot and should not escape its "destruction" as a troublesome import of the West' (Vellem 2020:7). The reason for this assertion is that democracy as a Western concept is hazardous to the agency of black African people (Vellem 2020:7). The tendency to romanticise about democratisation undermines its 'destruction' as a Western import.

Vellem's bold statement is based on racial elements expressed by a section of white individuals nostalgic about the apartheid era. These racial tendencies undermine political emancipation and the democratic gains premised on unity of all South Africans.

However, political emancipation without economic freedom is meaningless, and hence the importance of political and economic transformation. The paradigm shift from an 
exclusive political economy premised on white privilege and supremacy to a transformative macroeconomic policy framework was fundamental for South Africa. The transition to RDP as a macroeconomic policy framework recognised the role of the majority of black working class in the economy as critical in the African National Congress (ANC) government. This was a pro-socialist macroeconomic policy framework conscious of the inequalities created by a racial capitalism.

The proponents of capitalism, such as Adam Smith, suggest that it is a natural and absolute mode of production (Larraine 1989:6) that is ideal for the regulation of the economy. Karl Marx refuted this claim by arguing for alternative methods (Larraine 1989:6) of regulating the economy to ensure equity. The international economic policy theories and debates influenced South Africa's political economic changes.

Vellem provides an analysis of the political economic transition (Vellem 2013:2) post-1994, a move from RDP to Growth, Employment and Redistribution (GEAR) as a macroeconomic policy framework to the New Growth Path (NGP), with a focus on job creation for the majority of black communities (Vellem 2013:2). The transition from RDP to GEAR and to the NGP created uncertainty in government's economic policy. This was a return to a capitalist macroeconomic policy. Furthermore, Vellem (2010) argues that 'the undemocratic nature of the dominant and hegemonic neoliberal impulse in the politics and economy widens the gap between poor and rich' (pp. 1-6).

The GEAR policy was influenced by the neoliberal economic paradigm based on the Structural Adjustment Programmes drafted by the Bretton Woods Institutions in the United States of America. Vellem (2013) argues that capitalism's logic is questionable because of its distortions arising from its calculative rationalisation (p. 2). The modern economic system is repugnant and nothing short of a distorted capitalist narrative of 'get rich', which subjects the black working class to systems of debt and enslavement devoid of economic liberation. The capitalist economic system is based on extraction of resources from the poor.

The tributary system augments the systemic and structural inequalities between countries and people across the globe. The rich countries (centre) extract economic resources from the poor countries (periphery) in the same way that white people (oppressors) extracted economic resources from black people (oppressed) through an illegitimate political system of exploitation and cheap labour in South Africa.

The high rate of unemployment, poverty and inequality affects the black working class poor the most. Vellem argues (2020):

[W] hen the promises of political liberation crumble and fall in the face of millions of black bodies unemployed, viciously excruciated by poverty and growing inequalities inside and outside a given country, even in the same countries that are known to be well-developed, coloniality, the festering 'colonised wound' hidden in the language of salvation, progress and modernisation needs no doctorate to grasp - blackness is enough. (p. 4)

Vellem's eloquent depiction of the broken promises of political liberation is not mere pontification or inconsequential rhetoric. It is informed by the promise of a 'better life for all' (Manala 2010:521) by the government of the ANC that left millions unemployed. Vellem (2012) is apprehensive about the 'eruption of the dangerous memory of the poor post1994' despite its suppression (p. 1).

The poor have not forgotten the promise of a 'better life for all' through the provision of service delivery (Manala 2010:521-531), post-political liberation. The service delivery protests that are synonymous with the election periods demonstrate this dangerous memory of the poor. As long as these contextual realities of black people persist unabated, BLT will remain as an important instrument for theological reflection in South Africa. Gerald West argues that the ANC's use of religion in the public realm was a reflection of the departure from the RDP of the economy to the RDP of the soul (West 2007:1-32). The ANC was gradually shifting from a discussion on the RDP of the economy to the RDP of the soul (ANC 2007:2). The new RDP of the soul was an indication that the faith community needed to participate in moral and spiritual regeneration in the community. The new RDP of the soul recognised faith communities as important. However, the dominant narrative within the ANC was that faith communities can contribute to moral and spiritual regeneration but not necessarily economic development.

\section{Black liberation theology: Reflection}

It is inconceivable to reflect on faith without the recognition of economic and political injustices of apartheid in the South African context. Black liberation theology as an instrument of faith is critical in economic and political reflection in South Africa post-1994.

The BLT was born out of a context of oppression, which necessitated a theological reflection based on the liberation of the majority of black people around the world, especially in Africa and Latin America.

A discussion on BLT without the recognition of James $H$. Cone is a disservice to its historical epistemological trajectory. The critical work of Gustavo Gutierrez (1973) on a theology of liberation contributed immensely to Cone's formulation of BLT in the United States of America and its influence on South Africa and the rest of the world. Gutierrez formulated the notion of nonpersons (or non-being) (Gutierrez 1978:241) as a contested concept. This concept was central in the discourse of BLT challenging racism.

Cone (1970) argued vehemently that 'black theology of liberation was born in the courage to affirm being in the midst of non-being' (pp. 50-53). Vellem (2020) seems to share Cone's sentiments when he argues that 'BLT 
hermeneutics is not about the echoes of Western cannons of knowledge, but the embers of hermeneutics in the Zone of non-being' (p. 4). The concept of 'being' is neither optional nor circumstantial; rather, it is existential and hence its affirmation. The distortion of the gospel by racist fundamentalists aimed at dehumanising black people undermined the importance of 'being' as an identity.

The tendency to assume that racism is inconsequential to the concept of capitalism is a distortion that is similar to the assumption that colonialism is not central to modernity (Vellem 2015:2). This distortion is an attempt to trivialise the impact of capitalism and instruments of racism and colonialism. As centuries of racial capitalism indicate, racism in South Africa cannot be separated from capitalism as a tool of control and manipulation of the majority of black working class.

The black working class church rejected racism, colonialism and capitalism. The use of religion, in particular the Bible, to undermine the black church exacerbated the problem of racial and capitalist marginalisation of black people. God speaks from the perspective of the poor (Modise 2015, 3-4) in the midst of social and economic marginalisation. The Bible in the South African context remains a contested terrain.

\section{The Bible: Rethinking}

The black theologians in South Africa rejected the dominant white theology in support of a redemptive prophetic theology of liberation (Mosala \& Tlhagale 1986:47). However, did they reject the Bible in their rejection of white theology?

In challenging a black church, Boesak (2017:207) warned against white theology and challenged the black church not to engage in a theology that kept the Bible imprisoned to oppressive appropriation and subservient to a Christianised colonised mindset. Mofokeng (1998) also recognised the importance of the Bible for the oppressed, stating that it is a 'Haven for Black masses' (p. 40). In response to Mofokeng, the pertinent question that Boesak seems to ask is, 'in what way is the Bible a "haven for black masses"?'.

Boesak is challenging the reasons as to why the Bible is considered the 'haven for the Black masses' in the first place. Is it because it is applied uncritically by the 'black masses' to their struggle, hence its grasp as the 'haven', or is it because it is a source of liberation and a tool to challenge white racist theology oppressing black people?

The colonised mindset that is oblivious to the toxic appropriations of the Bible relates to the former rather than to the latter. The colonised mindset assumes the existence of an imaginary white God of the Bible who cannot be rejected. Furthermore, for Boesak (1977), the 'greatest ally of the oppressor is the mind of the oppressed' (pp. 5-6). The Black Consciousness Movement (BCM) challenged the mind of the oppressed to reject racial oppression and embrace blackness as an identity. The BCM contributed to the birth of BLT in South Africa.

Boesak (2017:194-226) argues that the church needs an alternative redemptive liberation paradigm against this dominant oppressive white theology narrative. Without a redemptive confessional prophetic narrative, the black church fails to articulate a genuine BLT that can effectively challenge forms of racial exclusion when they manifest. For Boesak, Black theology is primarily concerned about the God of the Bible who is different from the God whites have preached to the black church (Boesak 1984:10). Furthermore, biblical hermeneutics of liberation must be concerned with a liberating biblical discourse in appropriating the gospel and rejecting narrow perspectives imposed by the Western racist ideology. Boesak (1984:10) refuses to accept a narrow appropriation of the gospel based on the racist ideology the white Christians have made of it.

Furthermore, James Loubser concurs with Boesak and argues that there was a theological justification of apartheid in the use of the Bible in South Africa (Loubser 1987:33). The theological justification of apartheid in South Africa emerged from the Afrikaner traditional churches, the NGK or the Dutch Reformed Church (DRC). Boesak (2005) is apprehensive about 'the claim by the Afrikaner that apartheid could be morally justified as a Christian policy' (p. 117). The DRC's effort to justify apartheid as a Christian policy was an attempt to provide theological rationalisation for apartheid in South Africa (Johnston 1994).

Mosala (1989) wonders why Black theology in the United States of America and South Africa, respectively, failed 'to become a viable theoretical weapon of struggle in the hands of exploited masses themselves' (p. 13). The pertinent question therefore, I think, is 'what should have been the approach to the masses who are oppressed?' Is the Bible a viable instrument to liberate the masses from white racist theology? Colonial appropriations of the Bible suggest that it is not, however postcolonial hermeneutics challenges the colonial dominant narrative of the Bible. The redemptive Bible is significant to the future of BLT in South Africa.

Mosala (1986a) suggests that:

BLT has to take into consideration its cultural hermeneutics of struggle from a critical reappropriation of black culture just as African theology must consider political hermeneutics that arise from contemporary social struggles of black people under apartheid capitalism. (p. 99)

Both Boesak and Mosala are apprehensive about the ambiguous role of the Bible within the South African context of Black theology.

The strategies of imperialists included, amongst other things, using the Bible to demonise cultural identities of the oppressed. The demonisation of African culture emerges from a colonised appropriation of the Bible as a result of 
missionary indoctrination of black communities. Black liberation theology is, therefore, critical in the deconstruction of imperialist hermeneutics and the important role of the black working class interlocutor.

\section{Black interlocutor}

Black liberation theology is one of the pillars of African theology that needs preservation and protection from the oppressors. Failure to do this will lead to constant marginalisation of the black interlocutor. Vellem (2013:2) attributes this distortion to the exclusion of the black working class interlocutor in economic reforms. Vellem's (2013:2) analysis of the economic context postulates the importance of black working class interlocutor's space in the transition from a traditional to a modern economy.

The ontological black is significant in the BLT project, especially with regard to the pertinent question of who should be part of the discussion. Is the BLT project for the black working class, the middle class or both? What is critical in responding to this question is the contribution of the black interlocutor to the discussion about economic and political emancipation.

However, Mosala (1989:143) argues that it is not every black person that can do black theology. Mosala argues against the idea of a community of black people doing black theology on the basis of their ontological blackness. It is the black poor that is the ideal interlocutor in the BLT that seek to deconstruct racial ignorance and oppression of one by another.

Maluleke's (1996) perspective is that black theologians should identify a 'community of interlocutors - not informants, objects or beneficiaries within the diverse Black community' (p. 316). Furthermore, according to Maluleke (1996:316), the South African experience of the affirmative action (AA) has tended to focus on middle-class talk shop. This focus on the middle class 'talk shop' has undermined the importance of the black poor working class as the interlocutor. Vellem (2020) argues that 'BLT has distinguished itself from Western orthodox theology by choosing the "nonperson" as its interlocutor' (p. 3). The 'non-person' is the ideal interlocutor in the South African experience of economic exclusion, chronic unemployment, abject poverty and huge income inequalities affecting the black poor working class. Part of the problem, Vellem (2020:3) argues, is the influence of Western theology that has focused on the 'non-believer' as the interlocutor in the South African context. This type of theology fails to recognise the contextual ideological realities.

Both Maluleke and Vellem are concerned about the ideological posture in the choice of the black interlocutor. Both seem reluctant to gravitate towards the middle-class 'talk shop', but problematise the concept of 'non-person' with the aim of redeeming it. The working class black interlocutor challenges the orthodox notion of 'non-person' that describes the black poor.
I subscribe to the notion that contemporary theological reflection requires black intellectuals as individuals and as a community of black people with a particular ideo-theological posture to ask pertinent questions about who the interlocutor is in the process of liberation. The question, therefore, is who should reimagine black theology? The notion that the ontological black community is an important part of the process of reimagining is the beginning of such a process. However, the choice of who should reimagine is contested, and it raises the debate about what qualifies 'black theologians' as Maluleke argues, to identify a community of interlocutors? In other words, what criteria are being used to determine the choice of an interlocutor by the black theologians?

It is neither the individual nor the community or group of black interlocutors that is important, but the majority of the black working class poor who can choose to collaborate with black theologians in taking their position at the table as ideal black interlocutors. The working class interlocutor, which includes the majority of the poor and the marginalised, needs the experience of the black theologians in the reimagining process of BLT.

\section{Contemporary Black liberation theology: Reimagining}

The question of the relevance of contemporary BLT is not new. Simon Maimela (1984:49) argued long before the advent of democracy that contextual challenges confronting society, especially those deprived, oppressed and, therefore, in need of liberation, be it political, economic or sociocultural, justify the existence of BLT. Maimela further argued that BLT was necessary to engage with the socio-economic and political struggle (Maimela 1994, vii). What justifies the reintroduction of this question is the persistent challenge of economic inequalities in South Africa post-1994 period. Is there a role for BLT post-1994 or has BLT run its race during the political transition in the South African political landscape?

Boesak (1984) argues that 'Black theology is a black understanding of the gospel' (p. 21). This black understanding of the gospel is premised on the economic and cultural identity of the black working class experience of oppression. Black liberation theology must be concerned with the type of faith that addresses the fundamental challenges of the black working class.

Theological debates have emerged about whether 'Black', 'Liberation' or 'African' theologies are still relevant today, especially with the work of Jesse Mugambi (Mugambi 1995) and Charles Villa-Vicencio (Villa-Vicencio 1992) advocating for a shift from these theologies to a theology of reconstruction post political oppression (Adebo and Harold 2013, 2-3).

The primary focus of BLT since its inception has always been about Black and Liberation theologies within an African 
context. The theological reflection that engages with the socio-economic and political liberation is critical. In this context, racism became BLT's public enemy. Tshaka and Makafane (2010:538) argue from a black theology perspective that when one considers the contemporary socio-economic position of the people in South Africa, it is evident that an old system clothed in a new garment continues what colonisation and apartheid began centuries ago. How legitimate is this critique in the contemporary economic and political context of South Africa?

Tshaka and Makafane's (2010) critique is legitimate for two reasons. Firstly, the contemporary socio-economic system is still racially based with the economy controlled by white conglomerates, especially in the banking sector, as well as in mining and agriculture, to name just a few. These sectors are predominantly controlled by white businesses with the majority of black people as ordinary workers. Secondly, the ideo-theological position of the black church has failed to constantly provide a relevant BLT to militate against the socio-economic atrocities.

The exponential increase in youth unemployment, abject poverty and income inequalities suggests a crisis for the economy. The reimagining of BLT post-1994 is a cultural, contextual, hermeneutical and ideological importance for the poor and the marginalised individuals and communities. In the midst of contemporary challenges, the church (as a body that integrates all social classes) cannot afford to be silent, but to speak against all forms of social, economic, political and health problems confronting the country.

It is not yet Uhuru, the black poor are still suffering. I propose three important contextual theologies for the reimagining of BLT post-1994.

Firstly, solidarity theology is concerned with providing the solidarity support to those affected by social ills, be it health, social, economic, political or religious suffering in their context. Solidarity theology focuses primarily on social analysis of the community context with the intention of understanding contemporary challenges, such as coronavirus disease 2019 (Covid-19), human immunodeficiency virus (HIV) and acquired immunodeficiency syndrome (AIDS), gender-based violence, land dispossession, unfair labour practices, unemployment, poverty and inequality. The solidarity theology is empathetic rather than sympathetic in its approach. It is premised on the notion of Simunye [we are together], there is no 'us' and 'them' but 'togetherness', which suggests that 'I am because of others' in the community.

The secondary emphasis for solidarity theology is a pragmatic (directly collaborating with the affected irrespective of their class, gender or race) approach rather than an academic response to challenges. Solidarity theology proposes to offer both analysis (in the form of written material) and pragmatic (in terms of action to transform oppressive conditions) responses to contemporary problems. As a tool of social analysis, the solidarity theology employs the concept of 'space' to examine the context (West \& Zwane 2020:9). The solidarity theology engages critically with oppressive, controlled and dominated 'invited spaces' organised by the elites in cahoots with their grassroots allies masquerading as the vanguard of the working class (Zwane 2020:4).

Having done this, the next layer is to engage the powers that are to respond to these initiatives through prophetic theology. Black theology and prophetic theology are both about the transformation (Vellem 2016:9) of communities. Solidarity theology, like prophetic theology, is critical of religious rhetoric that does not translate into social transformation.

Secondly, prophetic theology is a critical biblical and theological 'voice' that engages directly with scriptures as a site of struggle in search of an alternative theological narrative to engage the structures and systems of oppression. Prophetic theology is premised on the idea of 'reading the signs' (Vellem 2010:1-6) of our time and speaking theologically and prophetically to the situation. It is the time to 'read the signs' of our time once again on the Covid-19, HIV and AIDS, gender-based violence, unemployment, poverty and inequality, and land question. These issues are important for political and economic sustainability.

It is in this context that prophetic theology becomes an instrument of economic justice and transformation. In the 1985 Kairos Document, the prophetic church stated that (Theologians 1986):

[T] he time has come. The moment of truth has arrived. South Africa has been plunged into a crisis that is shaking the foundations and there is every indication that the crisis has only just begun and that it will deepen and become more threatening in the months to come. It is a Kairos or moment of truth not only for the Apartheid but also for the church. (p. 1)

This statement by the church is as relevant today as it was in 1985 when the Kairos Document was written in the midst of apartheid in South Africa. Political and religious leaders fought against the white colonial system that marginalised and discriminated against people on the basis of race. It was prophetic theology that brought the apartheid regime to its knees using redemptive biblical and theological narrative.

Prophetic theology finds expression in redemptive energised and revitalised 'Invigorated spaces' of resilience that affirms the participation of the poor and marginalised communities (Zwane 2020:10). When religious leaders together with communities articulate prophetic theology as an alternative theological narrative, it rekindled their agency. It is this agency and action of resistance against marginalisation and exclusion that changed South Africa's political context. Pragmatic action ultimately leads to transformational theology.

Thirdly, transformational theology is based on mobilisation and resistance taking into cognisance the array of social, economic, political and religious challenges that need 
transforming. It is an action theology that seeks to transform oppressive structures in the public domain. It is a theology that is informed by solidarity and prophetic theologies that find expression in praxis. It is a see-judge-act movement from ignorance to informed analysis that is imbedded in the lived experiences of the poor and marginalised sectors in the community (West \& Zwane 2020:7). It is freedom from social, economic, religious and political oppression of communities. Religion is often the oppressor in most communities of the poor and marginalised, hence the need for a transformational and liberating theology. Transformational theology finds expression in the 'Invented spaces' of interpretive resistance that mobilises the poor and marginalised social movements (Zwane 2020:18) to challenge the dominant narrative of domination and oppression.

Each of these contemporary theological trajectories solidarity theology, prophetic theology and transformational theology - finds its place within the work of the Ujamaa Centre for Biblical and Theological Community Development and Research. ${ }^{1}$ The Ujamaa Centre's Theory of Change (ToC) is founded on the tenets of liberation theology (West 2016:136) and it argues that religion cannot be left 'as is' whilst development work is done (West 2016:142).

West (2016) challenges the narrative that religion and development cannot co-exist. Redemptive use of religion can be a tool for transformation. Doing development is doing transformational theology. Black liberation theology, therefore, has to underscore the importance of social change in the transformation project post-1994.

\section{Conclusion}

The relevance of BLT continues to be an important point of discussion in both the academia and community.

As long as there are elements of racism, HIV and AIDS, gender-based violence, economic injustices, unfair labour practices, land dispossession, unemployment, poverty and inequality and no access to healthcare for the poor, the debates about the role of BLT will continue as expected. There are four related important observations for the relevance of BLT in post-1994 South Africa.

Firstly, the political and economic transition from oppression under the Dutch and British colonies to the democratic dispensation post-1994 was critical for peace and stability. The political and economic periods that marked the transition to democracy were characterised by racial division. Both Dutch and British colonies contributed to the oppression of the majority of black people in South Africa. Secondly, white racist theology creates a need for political and economic reflection in the South African context. This transition is not an event but an ongoing process justifying continuous critical engagement in the community.

1.A University of KwaZulu-Natal Centre for Biblical and Theological Community Development and Research.
The existence of hegemonic and oppressive systemic and structural institutions provides for the emergence of an alternative 'voice' of liberation. Black liberation theology, therefore, was and still is an important 'voice' against dominant and hegemonic systems and structures of the church, politics and the economy. The BLT approach to the Bible in search of a redemptive and liberating theological narrative is fundamental.

Thirdly, the location of the Bible and black interlocutor amongst the 'black masses' necessitate a rethinking on the role of BLT in many ways. The Bible offers both redemptive and oppressive narrative to black people depending on their hermeneutical approach and contextual realities. The realities of many black interlocutors necessitate a discussion on the relevance of BLT in post-1994 democratic dispensation.

Fourthly, in reimagining of contemporary theologies it is important to engage with the economic and political status quo in both public and private institutions in South Africa. These theologies, like the Kairos Document in 1985, are challenging BLT and the church in general to once again 'read the signs' of time and utilise the 'space' to speak theologically and prophetically in the midst of despair.

\section{Acknowledgements}

The author would like to thank Prof. Gerald West for providing assistance in the editing of this article.

\section{Competing interests}

The author has declared that no competing interests exist.

\section{Author's contributions}

I declare that I am the sole author of this research article.

\section{Ethical consideration}

This article followed all ethical standards for a research without direct contact with human or animal subjects.

\section{Funding information}

This research received no specific grant from any funding agency in the public, commercial or not-for-profit sectors.

\section{Data availability statement}

Data sharing is not applicable to this article as no new data were created or analysed in this study.

\section{Disclaimer}

The views and opinions expressed in this article are those of the author and do not necessarily reflect the official policy or position of any affiliated agency of the author. 


\section{References}

Adebo, A.O. \& Harold, G., 2013, 'The relevance of Black Theology in post-apartheid South Africa, Cape Town', 1-15.

African National Congress, 2007, Section 7: RDP of the Soul: Umrabulo, Umrabulo Publisher, Johannesburg. https://www.anc.org

Boesak, A., 1977, Farewell to innocence: A socio ethical study on Black Theology and Black Power, Wfp \& Stock, Eugene, OR.

Boesak, A., 1984, Black and reformed: Apartheid, liberation and Calvinist tradition, Wipf and Stock Publishers, New York, NY.

Boesak, A., 2005, The tenderness of conscience: African renaissance and the spirituality of politics, Sun Press, Stellenbosch.

Boesak, A., 2017, Pharaohs on both sides of the blood-red waters: Prophetic critique of empire: Resistance, justice and the power of the hopeful Sizwe - A transatlantic conversation, Wfp \& Stock Publishers, New York, NY.

Cone, J.H., 1970, 'Black consciousness and the Black Church: A historical-theological interpretation', Animals of American Academy of Political and Social Science 387(1), 49-55. https://doi.org/10.1177/000271627038700107

Gutierrez, G., 1973, A theology of liberation, Orbis Books, Maryknoll.

Gutiérrez, G., 1978, 'Two theological perspectives: Liberation theology and progressivist theology', in S. Torres \& V. Fabella (eds.), The emergent gospel: Theology from the underside of history, pp. 227-255, Orbis, Maryknoll, NY.

Hankela, E., 2014, "'We are not liberated Yet in South Africa": Liberation Theology and the concept of humanity in inner-city Johannesburg', Religion and Theology 21(1-2), 173-206. https://doi.org/10.1163/15743012-02101005

Johnston, D., 1994, 'The churches and apartheid in South Africa', in D. Johnston \& C. Sampson (eds.), Religion, the missing dimension of statecraft, pp. 154-177, Oxford University Press, New York, NY.

Kgatle, M., 2018, 'The prophetic voice of the South African Council of Churches: A weak voice in post 1994 South Africa', HTS Teologiese Studies/Theological Studies 74(1), a5153. https://doi.org/10.4102/hts.v74i1.5153

Larrain, J., 1989, 'Theories of development': Capitalism, colonialism and dependency, Polity Press, Cambridge.

Loubser, J.A., 1987, The apartheid Bible: A critical review of racial theology in South Africa, Macmillan, Cape Town.

Maimela, S., 1984, 'Black power and black rheology in South Africa', Scriptura 12(1984). 1-49.

Maimela, S., 1994, 'Culture, religion and liberation', in Proceedings of the EATWOT Pan African Theological Conference, AACC, Nairobi.

Maluleke, T.S., 1996, 'Do I, with my excellent PhD, still need affirmative action? The contribution of Black Theology to the debate', Missionalia 24(3), 303-321.

Manala, J.M., 2010, 'A reality or a pipe-dream? A Black Theology intervention in conditions of poor service delivery in the Democratic South Africa', Scriptura 105, 519-531. https://doi.org/10.7833/105-0-170

Modise, L., 2015, Liberation theology as doing theology in post-apartheid South Africa, theoretical and practical perspective, pp. 1-16, Department of Philosophy, Practical and Systematic Theology, UNISA, Pretoria.
Mofokeng, T., 1988, 'Black Christians, the Bible and liberation', paper read at the International Congress on Africa and the Bible held in Cairo, Egypt, 14-21st August 1987.

Mosala, I.J., 1986, 'The use of the Bible in Black Theology', in I.J. Mosala \& B. Tlhagale (eds.), The unquestionable right to be free: Essays in Black Theology, pp. 175-199, Skotaville, Johannesburg.

Mosala, I.J., 1989, Biblical hermeneutics and Black Theology in South Africa, Eerdmans, Grand Rapids, MI.

Mugambi, J.N.K., 1995, From liberation to reconstruction, Acton Press, Nairobi.

Terreblanche, S., 2002, A history of inequality in South Africa 1652-2002, pp. 5-21, University of Natal Press, Pietermaritzburg.

Theologians, K., 1986, The Kairos document: Challenge to the Church, rev. 2nd edn., Skotaville, Braamfontein.

Tshaka, R. \& Mabathoana, M., 2010, 'The continued relevance of Black Liberation Theology for Democratic South Africa today', Scriptura 105, 532-546. https://doi. org/10.7833/105-0-155

Vellem, V.S., 2010, 'Prophetic Theology in Black Theology, with special reference to the Kairos document', HTS Teologiese Studies/Theological Studies 66(1), 6 pages. https://doi.org/10.4102/hts.v66i1.800

Vellem, V.S., 2012, 'Interlocution and Black theology of liberation in the 21st century: A reflection', Studia Historiae Ecclesiasticae 38(suppl. 1), 345-360.

Vellem, V.S., 2013, 'A critical black analysis of the church's role in the post-apartheid struggle for socio-economic justice', Studia Historiae Ecclesiasticae 39(2), $113-130$.

Vellem, V.S., 2015, 'Black Theology of liberation: A theology of life in the context of Empire', Verbum et Ecclesia 36(3), art \# 1470, 6 pages. https://doi.org/10.4102/ ve.v36i3.1470

Vellem, V.S., 2016, 'Epistemological dialogue as prophetic: A black theological perspective on the land issue', Scriptura 115, 1-11. https://doi.org/10.7833/115-0-1201

Vellem, V.S., 2020, 'Hermeneutical embers from the "zone of non-being"', in J. Havea (ed.), Mission and context, pp. pp. 1-14, Lexington Books/Fortress Academic, Lanham.

Villa-Vicencio, C., 1992, A theology of reconstruction: Nation building and right, Cambridge University Press, Cambridge.

West, G.O., 2007, The ANCS deployment of religion in nation-building: From Thabo Mbeki, to 'The RDP of the Soul' to Jacob Zuma, pp. 1-32, University of KwaZuluNatal Press, Pietermaritzburg.

West, G.O., 2016, 'Recovering the biblical Story of Tamar: Training for transformation doing development', in R. Oden (ed.), For better of worse, pp. 136-142, Swedish Mission Council, Uppsala.

West, G.O. \& Zwane, S.S., 2020, 'Re-Reading 1 Kings 21:1-16 between community based activism and university-based pedagogy', Journal for Interdisciplinary Biblical Studies Activism in the Biblical Studies Classroom: Global Perspectives 2(1), 179-207.

Zwane, S.S., 2020, 'Invited, Invigorated and Invented spaces: Re-appropriating development approach to community participation', in J. Choi \& J. Rieger (eds.) Faith, class, and labor, pp. 1-24, Wipf and Stock, New York, NY. 